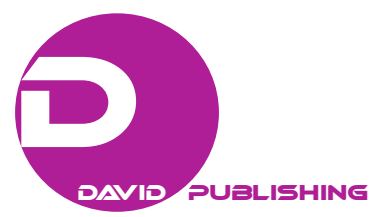

\title{
Bazin and Merleau-Ponty: Film and Its Ontological Bet
}

\author{
Julio Bezerra \\ Universidade Federal do Rio de Janeiro, Rio de Janeiro, Brasil
}

\begin{abstract}
There is a harmony between André Bazin’s and Maurice Merleau-Ponty’s approaches to cinema. They both see cinema as a new imperative language to express the being, capable of reflecting on our promiscuity with the world and things. Both realized the ontological bet that the game of imagination contains: the emergence of the image wrapped in a back and forth movement, from things to form, from fact to sense and meaning, and vice versa. The purpose of this article is to discuss Merleau-Ponty's and Bazin's interest in an ontological investigation of the cinema, analyzing their affinities and differences, identifying paths to be explored and affirming a certain idea of cinema.
\end{abstract}

Keywords: Maurice Merleau-Ponty, André Bazin and ontology

\section{Introduction}

Cinema is an intimate relationship between total artifice and total reality. It is the likeness of an icon and the imprint of an index. Cinema is the possibility of the presence of pure duration within temporal construction, of new relationships between continuity and discontinuity. It marks a new relationship between appearance and reality, between a thing and its double, between the virtual and the actual. "Cinema is a paradox", says Alain Badiou, always revolving "around the question of the relationship between 'being' and 'appearing'” (Badiou, 2013, p. 207). Its question, the subject of cinema, is really the problem of "being”. It is the art of breaking dualisms: finite and infinite, substance and accident, soul and body, sensible and intelligible. Cinema is an ontological art.

Many critics, philosophers and thinkers of varied fields have long said as much. Maurice Merleau-Ponty and Andre Bazin are among them. Merleau-Ponty approached film in two moments. In "The Film and the New Psychology”, early in his philosophical career, he identified a convergence between phenomenology and cinema: a common intention to make us relearn how to see the world. By the end of his life, when he realized that his first works had been unable to conceive of the unity of the phenomenal body and the objective body, film was approached one more time, albeit briefly, in a line of thought interrupted by the philosopher's premature death. What is noticeable is the possibility of an ontological account of film, emphasizing, particularly, its non-mimetic aspect as a presentation of the unpresentable.

At this moment, in the notes of one of Merleau-Ponty's last courses, the philosopher cites Andre Bazin, expressing his desire to incorporate cinema into the reflections that he had been developing about literature and painting, which were able, each in their own way, to establish the relationship between the visible and the invisible. Citing André Bazin could not be more exciting. There is indeed a harmony between the critic and the phenomenologist. Bazin and Merleau-Ponty see cinema as a new imperative language to express the being,

Julio Bezerra, Post-Doctoral Researcher, Universidade Federal do Rio de Janeiro. 
capable of reflecting on our promiscuity with the world and things. Both realized this ontological bet that the game of imagination contains: the emergence of the image wrapped in a back and forth movement, from things to form, from fact to sense and meaning.

The purpose of this article is to investigate Merleau-Ponty's and Bazin's interest in an ontological investigation of the cinema, analyzing their affinities, identifying paths to be explored and affirming a certain idea of cinema.

\section{Merleau-Ponty: Deciphering Tacitly the World and Men}

Merleau-Ponty saw the various arts as allies. They help him to curb the struggle towards legitimizing the belief that we are in direct contact with the world. Cinema would call for his attention quite early in his philosophical career. "The Film and the New Psychology" (a Lecture he gave in Paris in 1945) dates from the same year Phenomenology of Perception was published, and therefore this famous essay shares with the first two works of the philosopher a question about the legacy of modern rationalism, on the split between the body and the reflective thinking, about the abandonment of seeing and feeling on behalf of the thought of seeing and feeling.

In "The Film and The New Psychology," the interest in cinema is associated with the notion of film as an "object of perception," capable of revealing or making explicit certain fundamental characteristics that mark our exchange with the world. According to Merleau-Ponty, the cinematic image demonstrates the natural link between the interior and exterior. For him, phenomenology and cinema converged, in particular, with respect to the themes of our relationship with the world and with others. Cinema would be a privileged place for the expression of a "world view," in which contingency, ambiguity, and the conception of man as being-in-situation are key elements. This is the argument behind "The Film and The New Psychology." It is in this direction that the philosopher will explore affinities between the seventh art and the new psychology (Gestalt), including film in his broader critique of the classical concept of perception.

The essay is divided into two parts. In the first one, Merleau-Ponty describes what he calls "classical psychology" as opposed to the "new psychology.” The first assigns a primary role to sensations, understood as specific effects of local excitations that the intellect and memory would have to compose successively in a unified framework. The second shows, on the contrary, that what should really be taken as originating is perception as a sensitive apprehension of a phenomenon as a whole. For Merleau-Ponty, perception cannot be seen as a promoter of a separation between sensation and the organizing intelligence, but as an organized activity that marks our bodily relationship with the world, a structured decipherment, preceding the intellect.

Merleau-Ponty wants to show us the kinesthetic character of perception. And the philosopher tries to demonstrate it with the concept of film as an object of perception, "not a sum total of images but a temporal gestalt" (Merleau-Ponty, 1991, p. 54). That is why montage and its effects attract Merleau Ponty as an example of a form that transcends the sum of its elements. And the example of melody is precisely the one Merleau-Ponty refers to when he comes to talk about the Kuleshov effect. He in fact introduces it by pointing out that it "clearly shows the melodic unity of films", the fact that the sense of an image depends on those that precede it and that the succession of these images creates quite another reality.

Merleau-Ponty underlines his belief that the art of a movie does not consist in describing things didactically or expounding ideas, but in creating a "machine language" in order to put the viewer in a certain sensitive state: 
The meaning of a film is incorporated into its rhythm just as the meaning of a gesture may immediately be read in that gesture: the film does not mean anything but itself. The idea is presented in a nascent state and emerges from the temporal structure of the film as it does from the coexistence of the parts of a painting. The joy of art lies in its showing how something takes on meaning-not by referring to already established and acquired ideas but by the temporal or spatial arrangement of elements. (Merleau-Ponty, 1991, pp. 57 \& 58)

If understood literally, this claim could also summarize the main meaning of Merleau-Ponty's lecture, in which he indeed affirms that "we can apply what we have just said about perception in general to the perception of a film." Our spontaneous perception is not analytic, but synthetic, and precisely for this reason it can be considered "cinematographical" by nature. In fact, within its synthetic character we find at work dynamics which are essential for providing us with the unity of a perceived form as well as that of a cinematic sequence: far from being "artificial," as Henri Bergson tends to define them, they contribute instead to the truth of our perceptions.

For Merleau-Ponty, a movie creates meaning in the same way that things do. Both are not directed to an isolated intelligence, but to "our power tacitly to decipher the world or men and to coexist with them". (Merleau-Ponty, 1991, p. 58) That is why the philosopher says movies don't offer us the thoughts of a character. What we see are gestures, glances, mimes. A character becomes visible through its behavior, its singular mode of being in the world, through the way he or she deals with what surrounds him or her. The spectator, in turn, is in a relation of immediacy with the world through the film. Watching a movie is not to read, nor to understand, but, above all, to feel and accept something whose meaning is not already given. A movie should not be considered as a support for certain ideas or themes, not even simply as an artistic work, but as a composite of form and meaning which we can only access through the exercise of perception. Hence the famous formula: "a movie is not thought; it is perceived" (Merleau-Ponty, 1991, p. 58).

And that is when the maximum convergence between film and the new psychology reappears: the common intention of making us relearn to see the world:

Phenomenological or existential philosophy is largely an expression of surprise at this inherence of the self in the world and in others, a description of this paradox and permeation, and an attempt to make us see the bond between subject and world, between subject and others, rather than to explain it as the classical philosophies did by resorting to absolute spirit. Well, the movies are peculiarly suited to make manifest the union of mind and body, mind and world, and the expression of one in the other. (Merleau-Ponty, 1991, p. 58)

It is rather curious that Merleau-Ponty never comes close to a criticism of the classical decoupage and, much less, to a defense of the use of depth of field or the long take. On the contrary, the phenomenologist celebrates the convergence of his philosophy with the reflections of some montage theories, quite the opposite of other great figures inspired by phenomenology such as Bazin, Ayfre and Michel Mourlet. "The Film and the New Psychology" is one of the first essays to engage in a dialogue between cinema and phenomenology. What makes it unique is, oddly enough, the fact that Neorealism is not mentioned, not even once. If, on the one hand, we can say that Merleau-Ponty's essay is prior to the explosion of this movement in Europe, on the other hand, it is not very difficult to see the philosopher's lack of familiarity with the film production of his time.

Merleau-Ponty would address cinema again, by the end of his life, when he realized that the unveiling of the field of perception was still dependent on categories derived from reflective philosophy, categories that Merleau-Ponty himself nevertheless denounces. It becomes clear to him that his first two books configured a kind of a preliminary work, whose philosophical significance was not clearly established. He had to pursue 
figuring out how much philosophical reorganization was called for by the discovery of the perceptual field. This way of proceeding would lead him to a project of radical reformulation of the categories at work until then. It results in the awareness of the necessity of bringing the results of "Phenomenology of Perception" to an ontological explication.

This was the purpose of the work originally titled The Origin of Truth but published under the title that Merleau-Ponty had adopted in the end, The Visible and the Invisible. I tend to feverously agree with someone like Renaud Barbaras (2004), it is only in this later work and in some contemporaneous texts that what was announced in the earlier investigations is genuinely realized and that Merleau-Ponty's philosophy is laid out in a complete form, as a philosophy of expression. In order to no longer run the risk of being interpreted as a mere appearance or as a "psychological anecdote," the description of the perceived is overcome by the philosophy of expression, and the philosophy of expression, grasped in all of its implications, is fulfilled in an ontological enterprise.

If in the Phenomenology of Perception the analysis of perceptual phenomenon allowed the phenomenologist to describe experience indicating the coupling between subject and object, between the body and the world, starting from the duality between these poles in order to reconcile them in the unit of the experiential field, in The Visible and the Invisible experience is described as dehiscence. To think about our relationship with being as dehiscence is to no longer see it as a fir, a fusion, or a coincidence, but as a fission which, from the primordial unity of the flesh, makes the body and the world, the observer and the observed, the subject and the object arise, each one for the other. In this movement, Merleau-Ponty claims that the ontological problem is the one to which all others should be subordinate to. Therefore, ontology cannot be a theism, a naturalism or a humanism. This position is reaffirmed in the last note of his unfinished book "Precisely what has to be done is to show that philosophy can no longer think according to this cleavage: God, man, creatures” (Merleau-Ponty, 1968, p. 274).

Merleau-Ponty returns then to the world from the phenomenon of expression, by grasping the very birth of sense instead of referring it straightaway to a perceptual ground. He wants to gain access to the genuine figure of the world as soil or source of expression. And the world, as the soil of the expressive movement, will have an infinite depth inherent in the fact that sense is never completely fulfilled. "Because”, explains Barbaras,

No expression erases itself in the face of a pure sense, because expression cannot claim to be nailed down in a full meaning. The world will be given only as withdrawal, as this "presence" which, through its obscurity, gives birth to expression without ever being absorbed into the expressed. Considered on the basis of expression, the world can no longer be defined through presence but as that whose being consists in exceeding every presentation. (Barbaras, 2004, p. 60)

The discovery of an originary, operative sense that stops short of signification is ipso facto the discovery of a world which is before every presentation. The universal is found no longer on the side of sense but on the side of the world; it is what feeds every expression while always missing from what reveals it. The world is what still has to be said within what expresses it and therefore is still withdrawn from what says it. To consider sense on the basis of expression is to consider the world on the basis of being. Thus, Merleau-Ponty notes, the world is really what is "more than all painting, than all speech, than every 'attitude', and which, apprehended by philosophy in its universality, appears as containing everything that will ever be said, and yet leaving us to create it” (Merleau-Ponty, 1968, p. 170).

The being is "that which requires creation of us for us to experience it" (Merleau-Ponty, 1968, p. 197) and "cannot be apprehended outside of an expression that fulfills it” (Barbaras, 2004, p. 65). Expression is not a veil 
draped over the world but, insofar as it is the very becoming of the world, what can open us to it. Its creation is an unveiling; the divergence that it establishes is just as much coincidence. Therefore what is at issue for philosophy is to find a way of speaking that reaches the world again as mute expression, that grasps the birth of expression in its heart, or rather, that initiates us to the world as the birthplace of expression. This is the central role of Merleau-Ponty's reflection on painting.

However, in this redescription of the sensible, in this movement in the direction of a new ontology, Merleau-Ponty also sketched out another approach to film. In some of his latest work's notes, it is possible to identify the desire for a philosophical approach of cinema. A desire to incorporate cinema into the reflections that he had been developing about literature and painting, which were able, each in their own way, to establish the relationship between the visible and the invisible. This rapprochement goes through the issue of vision as the reversibility of the flesh, "the precession of what is upon what one sees and makes seen, of what one sees and makes seen upon what is" (Merleau-Ponty, 1964, p. 188), an action which "encounters, as at a crossroads, all the aspects of Being” (Merleau-Ponty, 1964, p. 188).

It is well known how important is the notion of "flesh" to the later Merleau-Ponty. However, as Mauro Carbone (2015) reminds us, what is often forgotten is that "flesh" is another name for the "element" he also calls "Visibility." This latter term seems to be chosen in order to avoid references to either a subject or an object, and to gather together activity and passivity. In The Visible and the Invisible, Merleau-Ponty states that the element of "Visibility" belongs "properly neither to the body qua fact nor to the world qua fact," thus, because of it, "the seer and the visible reciprocate one another and we no longer know which sees and which is seen" (Merleau-Ponty, 1968, p. 139). Moreover, by "Visibility” Merleau-Ponty does not only designate the ensemble of visible things, but also the "lines of force and the dimensions suggested by visible things as their own interior and exterior horizon” (Carbone, 2015, p. 1).

Vision is incarnated and occurs in the milieu of the world. It cannot be described as the unfolding of a completely objective world before a ubiquitous consciousness. "This amounts to saying that vision advents as the actual presence of a visible world” (Barbaras, 2004, p. 156), says Barbaras. The world is never before me. It surrounds me, surpasses me. The world is immersed in me, invades me, fills me. Although I am "within” it, there is no way to mark a limit between the world and me, between what would belong to it and what I would hold as my own. We are made of the same texture. In other words: to see something is not to see it itself but to see in or by it. Vision emerges as a moment of the thing, a moment which cannot be detached from it.

That is precisely what Merleau-Ponty says about painting in "Eye and Mind”: "I do not look at [...] [a painting] as one looks at a thing, fixing it in its place. [...] Rather than seeing it, I see according to, or with it" (Merleau-Ponty, 1964, p. 126). The analysis of the act of vision shows us that the work of an artist consists, above all, in an ontological recovery of the world. Painting, for example, tries, through the spectacle of the visible that a painting celebrates, to express, in a way, all aspects of being.

Merleau-Ponty is talking about paintings, but he is actually delineating a general conception of vision. We see him going in such a direction in the preparatory notes for an unfinished course titled "Cartesian Ontology and the Ontology of Today.” These notes present the course, underlining that the subject after which it is titled

is not the history of philosophy in the current sense: what has been thought, it is: what has been thought in the context and the horizon of what one thinks-Evoked in order to understand what one thinks. Rather: Contemporary ontology—starting from this, then towards Descartes and Cartesians, and back to what philosophy can be today. (Merleau-Ponty, 1996, pp. 390-391) 
While trying to provide contemporary ontology with a philosophical formulation, Merleau-Ponty end up referring to cinema and citing André Bazin: "André Bazin ontology of cinema (...) In the arts / Cinema ontology of cinema-example the question of movement in cinema” (Merleau-Ponty, 1996, pp. 390-391). It is no surprise then, as Carbone highlights, that most traces of the later Merleau-Ponty's reflections on cinema concern more directly precisely the question of movement. Although he doesn't develop further his comments to cinema, it is evident his emphasizes on the nonmimetic feature of film realism. What is noticeable in the horizon is the possibility of an ontological account of film.

\section{André Bazin: Cinema and the Apprehension of the Real}

To talk about André Bazin could not be more instigating. Bazin and Merleau-Ponty seem to share some affinities when it comes to cinema and its ontological bet: the emergence of the image wrapped in a back and forth movement, from things to form, from fact to sense and meaning. Bazin was the most brilliant representative of the new post-war French criticism. He did not share the pessimism with which the old generation, still in mourning for the silent movies, faced the industrial cinema, and defended Hollywood cinema like few. Imbued at the same time with the Catholic idealism of his time and Sartrean existentialism, Bazin saw a great pedagogical potential in the cinema and, challenging the formative tradition, proposed a new history for it.

Serge Daney once referred to as the editorial line of Cahiers du Cinéma, something which amounts to the genealogy of an "idea of cinema", an idea embodied in the films of Roberto Rossellini, Jean Renoir and of the New Cinema auteurs from around the world. Daney affirmed a certain axiom, which he traced back to Bazin: "Cinema has a rapport with reality and that the real is not what is represented" (Daney, 1993, p. 301). As Dudley Andrew (2010) stresses, Daney actually adapted this axiom from Eric Rohmer, whose eulogy for Bazin in the January 1959 issue of Cahiers suggested that in Bazin's collected writings

Each article, but also his entire ouevre, has the rigor of a real mathematical proof. All of Bazin's work is centered on one idea, the affirmation of cinematic 'objectivity,' in the same way that geometry centers on the properties of the straight line. (Rohmer, 1959, p. 32)

Bazin, at least as Rohmer portrays him, as he would until today be not entirely accurately associated with, unswervingly developed a realist system. Just like "Euclid's straight line," photographic reference would serve as this system's first base. Bazin does insist that cinema has to be defined apart from the other arts, for cinema possesses a very specific, very intrinsic link with living reality. It is in his essays on the Italian neo realism that these issues would be treated and originally developed. Cinema rediscovered in Italian neorealism another specificity, lost in the theories of montage of the beginning of the century: its intrinsic realism, its ability to represent reality without human intervention, preserving it in a multitude of ways. In celebrated essays (such as "Ontology of the Photographic Image" and "The evolution of film language"), Bazin traces the history of verisimilitude and realism from the fine arts, and identifies in photograph and cinema the advent of a different stage, the possibility of a better match between image and object:

In achieving the aims of baroque art, photography has freed the plastic arts from their obsession with likeness. Painting was forced, as it turned out, to offer us illusion and this illusion was reckoned sufficient unto art. Photography and the cinema on the other hand are discoveries that satisfy, once and for all and in its very essence, our obsession with realism. No matter how skillful the painter, his work was always in fee to an inescapable subjectivity. The fact that a human hand intervened cast a shadow of doubt over the image. Again, the essential factor in the transition from the 
baroque to photography is not the perfecting of a physical process (photography will long remain the inferior of painting in the reproduction of color); rather does it lie in a psychological fact, to wit, in completely satisfying our appetite for illusion by a mechanical reproduction in the making of which man plays no part. (Bazin, 2004, p. 12)

In passages like this we realize that the statement about the realism of cinema is based not just in a physical notion of reality, but in a psychological sense. "Photography affects us like a phenomenon in nature, like a flower or a snowflake” wrote Bazin (2004, p. 13). But he didn't say photography was a phenomenon in nature, only that it affects us that way. In a sense, realism has less to do with the accuracy of reproduction, but with the viewer's belief in the origin of reproduction. What counts, as Bazin stressed, is not so much the resulting image as its genesis. A painting may be more vividly observed and more accurately detailed, but the photographic image affects us as a peculiarly believable icon because we know it to be an imprint received directly from life. Not having been fashioned by human hands, the photograph is supposedly unencumbered by human subjectivity. "All the arts are based on the presence of man” Bazin (2004, p. 13) wrote "only photography derives an advantage from his absence".

A photograph is an image that partakes of the reality it represents. It receives a "transference of reality" from the thing it pictures, says Bazin. A painting is a handmade image and it carries in it something of the hand that made it. A photographic image is made of light. It employs a physics of light instead of painting's spiritual or transcendent light. The light the camera receives from reality is a material that belongs to the thing represented. Bazin is the one who taught us that light leaves a track like any other body, an imprint the camera makes into an image. A photographic image is an imprint of light, a trace left by a real body. Gilberto Perez (1998) summarizes:

Something of the thing itself comes through in its photographic representation. (...) No matter how fuzzy, distorted, or discolored, no matter how lacking in documentary value the image may be, it shares, by virtue of the very process of its becoming, the being of the model of which it is the reproduction; it is the model. (Perez, 1998, pp. 14 \& 27)

This possibility of a type of representation that excludes man and his subjectivity, would give reality the ability to speak for itself. Photography, as a sort of vestige of it, shows its existence, fixes it and returns it again to the world and to our attention. The notion of "ontology" comes at least initially from this reasoning. But the camera is not the only machine that makes the film image. The projector, the magic lantern, animates the track of light with its own light, brings the imprint of life to new life on the screen. The images on the screen carry in them something of the world itself, something material, and yet something transposed, transformed into another world: the material ghost, as Perez so beautifully describes. Besides: film is a practice of desembalming. The cinematographic image is no longer content to preserve an object. The image of things becomes also the image of their duration, "change mummified as it were" (Bazin, 2004, p. 15).

We should go back to Daney because he went beyond Rohmer’s Euclidian view of Bazin. For him, Bazin is closer to a calculus where negative as well as imaginary values come into play. Objectivity is a question of approximation. Bazin, as Daney and someone like Andrew underline, is in part a theorist of absence, whose mission was to show that before signifying it or resembling it, cinema embalmed the real. Bazin never claimed that photographic portraits represent their subjects. They rather are "grey or sepia shadows, phantomlike ... the disturbing presence of lives halted at a set moment in their duration” (Bazin, 2004, p. 14). Dudley Andrew is right: Bazin's theory is founded not only on the photograph but on the spectral. "Cinema confronts us with something resistant, to be sure, but not necessarily with the solid body of the world. Through cinema, the world 
'appears'; it takes on the qualities and status of an "apparition” (Andrew, 2010, p. 9).

Although based on photography, Bazin's ontology of cinematic realism is above all a theory about the inscription and storage of time, rather than being dependent on what we usually understand by image, namely mimesis and representation. In "The Ontology of the Photographic Image,” Bazin makes a curious distinction

Between true realism, the need that is to give significant expression to the world both concretely and its essence, and the pseudorealism of a deception aimed at fooling the eye (and for that matter the mind); a pseudorealism content in other words with illusory appearances (Bazin, 2004, p. 12).

For Bazin realistic traditions in art always combine these two tendencies. They shouldn't then be seen as mutually exclusive. Cinema may very well have both aspects and. Its originality as an art form lies neither in expressing individual subjectivity nor in simply reproducing certain traits and qualities as components of illusion, "but rather”, explains Tom Gunning (2011, p. 123), "in presenting the world in its own image, a task that must be more elusive than it might first appear".

In other words: Bazin had a dialectical understanding of the relation between realism, imagination, and illusionism. Let’s consider the following statement: “... cinematic reality could not do without... documentary reality, but if it is to become a truth of the imagination, it must die and be born again of reality itself” (Bazin, 2004, p. 47).

What Bazin truly means by "reality”? Documentary reality? Truth of the imagination? Renewal and self-effacement? Appropriation and destruction?

Depending on the meaning we give to each appearance of the word, Bazin's vision of cinema changes. He is no naïve realist, but rather sees reality and illusion, truth and belief as mutually interdependent.

If we reread his famous article on Vittorio De Sica's Bicycle Thieves (1948) it is noticeable once more how complex and nuanced Bazin's views on realism actually are. For him, "realism in art can only be achieved in one way-through artifice” (Bazin, 2005, p. 26). But at the same time Bazin imagines cinema's self-abolition, something he associates with De Sica's film: "No more actors, no more story, no more sets, which is to say that in the perfect aesthetic illusion of reality, there is no more cinema” (Bazin, 2005, p. 60).

Cinema is defined primordially as a "recording”, a "mechanical recording." While this may be a common way to identify Bazin, what is often misunderstood is the fact that cinematographic recording is not only a product of its mechanics. That is mechanics are necessary but not sufficient for cinematic recording. For during any technical recording, something else occurs, as something is recording and being recorded. Robert Bresson put it remarkably well in one maxim from Notes on the Cinematographer: "a mechanism gives rise to the unknown" (Bresson, 1977, p. 32). Something happens "in an obscure way" in the "models" of Bresson when a camera is recording before them: it frees them it liberates cinema itself from "photographic reproduction". We enter then in the realm of the unknown, of what is possible, but not yet known.

\section{Conclusion}

It seems that the reflections of Merleau-Ponty's interest toward Bazin's observations can hence be better understood. In fact, the theoretical convergence between the later Merleau-Ponty and Bazin seem to develop a new ontological consideration of vision and thus of the image. In the "The Ontology of the Photographic Image" Bazin wrote that "the logical distinction between what is imaginary and what is real tends to disappear. Every image is to be seen as an object and every object as an image” (Bazin, 2004, p. 14). In "Eye and Mind”, when 
reflecting on the novelties of modern painting, Merleau-Ponty claims in his turn that the image shall no longer be considered as "a tracing, a copy, a second thing" (Merleu-Ponty, 1964, P. 164) more or less faithful to its model, and anyway produced by a vision independent from our sensible relation to the world. In fact, for both of them, the imaginary can neither be conceived of as a substituting faculty, nor a surrogate for reality. The imaginary is not the opposite of the real, it rather emerges "together with vision itself from that sensible kinship between the world and us" (Carbone, 2015, p. 57).

While looking at the experience of the painter, Merleau-Ponty observes the moments in which to see, to hear or to speak cross through the layer of what is established and seem to strip the originating aspect of a visible, resonant and talkative world. For him, in modern painting the flesh is at stake- "both the flesh of things, and the flesh constituting each living creature's way of inhabiting the world” (Carbone, 2015, p. 21). In The Prose of The World Merleau-Ponty writes that "objects in a modern painting 'bleed,' their substance spreads under our eyes, they directly question our gaze, and they test the pact of coexistence that we have made with the world by means of our whole body” (Merleau-Ponty, 1973, p. 152). The philosopher is referring to Paul Klee's work, but we can extend it to film.

That is precisely what Bazin seems to do. In another famous essay Bazin locates the origins of cinema less in the progressive achievement of a scientific and industrial research project than in the obsessions of a handful of inventors. Bazin envisions a different kind of image. This unique image strives to achieve "the world in its own image”. His myth moves beyond subjectivity and objectivity, and even beyond materialism and idealism.

An image must be characterized as a chiasm. It is a thing of the world-it is entirely in the world, but the world is entirely in it. It makes the world appear, and the world exhibits itself in it. Barbaras talks about and “openness-opened”:

It is opened up, it is arranged, and it appears as a thing only if it is an opening, that is, on the condition that it leaves room for the world itself. It is opened up, then, only if it is itself the openness in which it appears. It is unified only in the measure that it is unifying; its unity overflows the limit that it nonetheless circumscribes; its unity is made generality, world. (Barbaras, 2004, pp. 189 \& 190)

Cinema is then a unique amalgam of mind and matter, beyond any subject-object division. For Bazin and Merleau-Ponty, this amalgam, fills the world, reorganizing the abstract and the concrete, the animate and the inanimate, the actual and the virtual, the general and the particular, necessitating a new classification of what exists, that is to say, a new ontology. Ontology here means the possibility to restore an originary articulation of the sensible and of sense. It is a possibility each image carries. Its ability to evacuate meanings and identities, to proliferate resemblances without sense or origin. It knows no structuring lack, no primordial division, but a conflictual continuity. A film should be seen as the founder of its own reality. Each film requires from us a thought that does not retreat before that uncertain and ambivalent experience that connects us, aesthetically, emotionally, sensuously, with the world. Before any critical and theoretical analysis, before the fragmentation and dissection of the image's most sensory and direct aspects in a terminology governed by either montage, misé-en-scène or syntagmatic categories, binary and oppositional structures, a film should be thought according to its ontological proposal.

With the help of both Merleau-Ponty and Bazin we can elaborated an ontological approach to cinema that challenges all clear distinctions and induces a singular experience of disorientation in the heart of the most familiar experiences. It is an undertaking that is meticulous, grave, and always to be taken up again. Thinking 
cinema with Merleau-Ponty and Bazin should mean accepting an adventure from which none of the words that serve as our reference points should emerge untouched, but from which none will be disqualified or denounced. All are a part of the problem. We shouldn't try to mitigate the contradictions and to make compatible that which defines itself as conflictual. To think with them about cinema is also to affirm that the success of a theoretical proposition of cinema is not to resist objections. Its aim should be not to deduce and impose norms or concepts about what cinema is or should be, but rather to make us more fully aware of how cinema escapes and upsets these ideas.

An ontological approach to cinema is a never ending interrogation. That is actually what Merleau-Ponty thought to be the very nature of philosophy: the interrogation of its own possibility. For him philosophy in the end coincides with this interrogation. It is "astonishment before oneself” (Merleau-Ponty, 1982, p. 172). By coming to terms with itself as such, philosophy will be able to clarify its astonishment before the world: to discover "interrogation as the ultimate relation to being and as an ontological organ" (Merleau-Ponty, 1968, pp. 162 \& 121), to discover consequently that "the existing world exists in the interrogative mode” (Merleau-Ponty, 1968, p. 139). Things are no different when it comes to Bazin. He dares to question: What cinema is? And this is a kind of a compass for him. A question which will never cease to be answered and posed, again and again. Because Bazin is ultimately the understanding that cinema is always ahead of us. Cinema already knows. Cinema is more intelligent and conceptual than us. Cinema has yet to be invented.

\section{References}

Andrew, D. (1976). The major film theories: An introduction. New York: Oxford University Press.

Andrew, D. (1985). The neglected tradition of phenomenology in film theory. In B. Nichols (Ed.), Movies And Methods: An Anthology (Vol. 2). Los Angeles: University of California Press.

Andrew, D. (2010). What cinema is! Bazin's quest and its charge. Oxford, UK: John Wiley \& Sons.

Badiou, A. (2013). Cinema. Cambridge: Polity Press.

Barbaras, R. (2004). The being of the phenomenon: Merleau-Ponty's ontology. Bloomington, IN: Indiana University Press.

Bazin, A. (2004). What is Cinema? (Vol. 1). Berkeley and Los Angeles: University of California Press.

Bazin, A. (2005). What Is Cinema? (Vol. 2). Berkeley and Los Angeles: University of California Press.

Bresson, R. (1977). Notes on the cinematographer. New York: Urizen Books.

Carbone, M. (2015). The flesh of images Merleau-Ponty between painting and cinema. Albany, New York: State University of New York.

Daney, S. (1993). L'exercise a été profitable, Monsieur. Paris: P. O. L.

Elsaesser, T. (2011). A bazinian half-century. In D. Andrew \& H. Joubert-Laurencin (Eds.). Opening Bazin. Oxford/New York: Oxford University Press.

Gunning, T. (2011). The world in its own image. In: D. Andrew and H. Joubert-Laurencin (Eds.). Opening Bazin. Oxford/New York: Oxford University Press.

Merleau-Ponty, M. (1964). Primacy of perception. Evanston, Illinois: Northwestern University Press.

Merleau-Ponty, M. (1968). The visible and the invisible. Evanston, Illinois: Northwestern University Press.

Merleau-Ponty, M. (1973). The prose of the world. Evanston: Northwestern University Press.

Merleau-Ponty, M. (1982). Résumé de cours, Collège de France 1952-1960. Paris: Gallimard.

Merleau-Ponty, M. (1991). Sense and non-sense. Evanston, Illinois: Northwestern University Press.

Merleau-Ponty, M. (1996). Notes de cours au Collège de France 1958-1959 et 1960-1961. Paris: Gallimard.

Merleau-Ponty, M. (2010). The sensible world and the world of expression. In Chiasmi internationl 12. Milano, Udine: Mimesis Edizione.

Perez, G. (1998). The material ghost: Films and their medium. Baltimore/London: The Johns Hopkins University Press.

Rohmer, E. (1959, January). La “Somme” d’André Bazin. In Cahiers du cinéma 91(January), 36-45. 